\section{Mechanical Harvesting Capacity in Sweet Orange Is Increased with an Abscission Agent}

\author{
Jacqueline K. Burns ${ }^{1,3}$, Richard S. Buker III ${ }^{1}$, and Fritz M. Roka ${ }^{2}$
}

AdDitionAl INDEX wORDs. canopy shaker, catch-frame, 5-chloro-3-methyl-4-nitro- $1 H$-pyrazole, fruit detachment force, fruit drop, mature fruit removal, trunk shaker

SUMMARY. An abscission agent [5-chloro-3-methyl-4-nitro- $1 \mathrm{H}$-pyrazole (CMNP)] was applied to 'Hamlin' and 'Valencia' orange (Citrus sinensis) trees at concentrations ranging from 0 to $500 \mathrm{ppm}$ in a volume of $300 \mathrm{gal} / \mathrm{acre}$. Four days after application, fruit were mechanically harvested with either a trunk shake-and-catch or a continuous canopy shake-and-catch system commercially used in Florida. Harvesting conditions were varied by limiting the actual trunk shake time of the trunk shaker to 2,4 , or 7 seconds, or by altering the ground speed of the canopy shaker $(1.0,1.5$, or $2.0 \mathrm{mph})$. In general, increasing duration of shake and the application of CMNP increased percent mature fruit removal and decreased the amount of fruit remaining in the tree. Increasing CMNP concentration decreased fruit detachment force but increased post-spray fruit drop. Comparison of short duration shake times in CMNP-applied trees with trees harvested at longer durations either sprayed or not sprayed with CMNP indicated no significant difference in percent mature fruit removal. The results demonstrate that CMNP application increases harvesting capacity of trunk and canopy shakers by reducing time necessary to harvest each tree while maintaining high percent mature fruit removal.

S ince the 1960s, Brazil has been aggressively expanding its citrus industry and as a consequence, global competitiveness of the orange juice industry has increased. This has caused the Florida citrus industry to identify practices that will reduce overall cost. Florida citrus is predominantly harvested by hand, and harvesting costs now exceed total production costs (Muraro et al., 2003). Interest in mechanical harvesting is driven by the need to reduce cost associated with current harvesting practices. Mechanical

${ }^{1}$ Horticultural Sciences Department, University of Florida, IFAS, Citrus Research and Education Center, 700 Experiment Station Road, Lake Alfred, FL 33850

${ }^{2}$ Food and Resource Economics Department, University of Florida, IFAS, Southwest Florida Research and Education Center, 2686 State Road 29 North, Immokalee, FL 34142 .

This research was supported by the Florida Agricultural Experiment Station and a grant from the Florida Department of Citrus (03-12) to the authors, and approved for publication as Journal Series No. R-10564. The authors wish to thank Josh Adkins, Fernando Alferez, Baylis Carnes, Rose Edwards, Barbara Hyman, Kuo-Tan Li, Luis Pozo, Ana Redondo, Shila Singh, Marcus Timpner, Katrina Van Tonder, Rongcai Yuan, Agricultural Machines, Inc., Coe-Collier Citrus Harvesting LLP, and Cooperative Producers, Inc., for their expert assistance and cooperation.

${ }^{3}$ To whom reprint requests should be addressed; e-mail address: jkbu@ufl.edu harvesting systems currently available for commercial operations are reducing harvesting costs by $15 \%$ to $20 \%$, and the potential costs savings are predicted to approach $50 \%$ when proper grove preparation and catching systems are incorporated (Brown, 2005). Despite these potential savings, adoption rate of mechanical harvesting systems has been slow. For the most part, growers have not seen sufficient decreases in harvest costs to induce them to prepare trees and put aside their fears of adverse tree health effects from mechanical harvesting.

One impediment to the successful adoption of mechanical harvesting systems is the availability of an abscission agent that could increase harvesting fruit, especially late in the season when capacity and selectively harvest mature the presence of mature and immature 'Valencia' fruit are present on the tree simultaneously. Currently, no abscission agents are registered for use on citrus. Incorporating an abscission agent into the harvesting system is expected to improve overall efficiency throughout the harvest season by increasing harvesting capacity of machines, further reducing cost. More acreage can be potentially harvested in a given period of time because loosened mature fruit can be harvested faster, while overall fruit removal will remain the same or higher. As harvesting capacity increases by extending the season through selectively loosening mature fruit or by allowing harvesting systems to harvest faster, unit cost of harvesting will decrease. As harvest costs decrease, growers will have incentive to harvest mechanically and the transition from hand harvesting to mechanical systems should accelerate.

The long-term goal of our research is to demonstrate the potential of abscission agents to increase mechanical harvesting acreage in Florida citrus. The effect of abscission agents combined with mechanical harvesting on late season 'Valencia' selectivity will be the subject of a future report. Substantially increasing harvesting capacity of mechanical systems is viewed as the economic blueprint for achieving harvest cost reduction goals of mechanical harvesting. The objective of the work reported here was to demonstrate the potential to increase harvesting capacity of commercially operating mechanical harvesters with the use of an abscission agent. The abscission agent used in our work, CMNP, is a selective compound that is non-phytotoxic within a wide concentration range (Burns, 2002; Wilson et al., 1977). We demonstrate that trunk or canopy shaker harvesting speed can be increased by using abscission agents without compromising mature fruit removal.

\begin{tabular}{llll}
\hline $\begin{array}{l}\text { Units } \\
\begin{array}{l}\text { To convert U.S. to SI, } \\
\text { multiply by }\end{array}\end{array}$ & U.S. unit & SI unit & $\begin{array}{l}\text { To convert SI to U.S., } \\
\text { multiply by }\end{array}$ \\
\hline 0.4047 & $\mathrm{acre}(\mathrm{s})$ & $\mathrm{ha}$ & 2.4711 \\
0.3048 & $\mathrm{ft}$ & $\mathrm{m}$ & 3.2808 \\
9.3540 & $\mathrm{gal} / \mathrm{acre}$ & $\mathrm{L} \cdot \mathrm{ha}^{-1}$ & 0.1069 \\
0.4536 & $\mathrm{lb}$ & $\mathrm{kg}$ & 2.2046 \\
1.6093 & $\mathrm{mile}(\mathrm{s})$ & $\mathrm{km}$ & 0.6214 \\
1.6093 & $\mathrm{mph}$ & $\mathrm{km} \cdot \mathrm{h}^{-1}$ & 0.6214 \\
1 & $\mathrm{ppm}$ & $\mathrm{mg} \cdot \mathrm{L}^{-1}$ & 1 \\
$\left({ }^{\circ} \mathrm{F}-32\right) \div 1.8$ & ${ }^{\circ} \mathrm{F}$ & ${ }^{\circ} \mathrm{C}$ & $\left(1.8 \times{ }^{\circ} \mathrm{C}\right)+32$
\end{tabular}




\section{Materials and methods}

SPRAY APPLICATIONS AND TEMPERATURE MEASUREMENTS. In all cases, CMNP was used as the abscission agent and applied $4 \mathrm{~d}$ before mechanical harvest. CMNP [17.2\% a.i., as previously formulated by Abbott Laboratories, Chicago (see Burns et al., 2003)] was applied at various concentrations as indicated below in a volume of 300 gal/acre using an air-blast sprayer (model MB-400-36 Pul-Blast; Rears Manufacturing Co., Eugene, Ore.). This volume was selected based on previous work that demonstrated high volume applications were required for more uniform deposition of CMNP, lower fruit detachment force and higher percent removal (Koo et al., 2000; Salyani et al., 2002). Spray solutions contained $0.125 \%(\mathrm{vol} / \mathrm{vol})$ Kinetic adjuvant (Helena Chemical Co, Memphis, Tenn). A randomized complete-block design was used for all experiments, with each row of trees considered a block. Four blocks were used in all experiments. In all cases, no rainfall occurred between time of abscission material application and harvest. Average hourly temperatures were obtained from the Florida Automated Weather Network's Immokalee weather station located at the Southwest Florida Research and Education Center, Immokalee (University of Florida, 2005). The weather station was located approximately 1 $\mathrm{km}$ southwest of the Dec. 2003 trial site, $2.4 \mathrm{~km}$ southwest of the Mar. 2004 site, and $15 \mathrm{~km}$ east of the Apr. 2004 site.

DEC. 2003 TRIAL-TRUNK SHAKER. Prior to application of CMNP, a 10-acre block of 15-year-old 'Hamlin' orange trees on Carrizo citrange (Citrus sinensis $\mathrm{x}$ Poncirus trifoliata) rootstock was selected in the Silver Strand North Groves near Immokalee, Fla. Within this block, 160 uniform trees at a spacing of $3.6 \mathrm{~m}$ in the row and $7.3 \mathrm{~m}$ between rows and covering approximately 1 acre were selected for study. Trees were divided into plots of five adjacent trees in the row separated by at least one guard tree. Any ground fruit under test trees were removed. Tree height and trunk circumference were measured on the center tree in each plot. A trunk shaker equipped with a catch-frame (trunk shake-andcatch system)(Coe-Collier Citrus Harvesting LLP, Immokalee, Fla.) was used for harvest and operated at constant force settings (proprietary) at either 2 or $7 \mathrm{~s}$ shake time per tree. Shake times were monitored with a stopwatch. Timing began when the canopy visibly began to shake and ended at the designated time by terminating power to the shaker head. CMNP was applied to tree canopies at $0,125,250$, and 500 ppm on 4 Dec. On the days of spray application and harvest, fruit detachment force [FDF (kilograms)] was measured on 20 randomly selected fruit from the center tree of each plot as previously described (Pozo et al., 2004). Fruit that dropped after spray application and before mechanical harvesting commenced were collected and counted. Post-spray drop weight was derived from individual piece weights of harvested fruit (see below).

Fruit caught in the catch frame after each plot of trees was harvested were conveyed to a modified holding truck and transported to pad scales. The truck containing harvested fruit was weighed and its tare weight subtracted to determine the weight of harvested fruit from each plot. Fruit harvested by the trunk shaker but not caught in the catch frame were counted. Total fruit weight was derived by using the weight of 20 individual pieces of fruit from each plot. Fruit that remained in the canopy after mechanical harvest were harvested by hand and counted, and the total weight derived as described above. Total fruit harvested by the trunk shaker + post-spray drop was determined by adding the weight of post-spray drop to the weight of fruit harvested by the trunk shaker + those caught or not caught in the catch frame. The mature fruit removal percentage was calculated by dividing total fruit harvested with the trunk shaker + post-spray drop by the total yield (total fruit harvested with the trunk shaker + post-spray drop plus the fruit remaining in the tree after mechanical harvest).

To determine the effect of CMNP concentration on FDF and post-spray drop, a simultaneous trial was conducted in an adjacent block of 'Hamlin' trees under the same management regime and rootstock. A total of 72 uniform trees were selected and divided into plots of three adjacent trees in the row separated by at least two guard trees. Ground fruit under test trees were removed. CMNP was applied at $0,31.3,62.5,125,250$, and 500 ppm on Dec. 4. FDF was measured daily for $5 \mathrm{~d}$ on 20 fruit randomly selected from the center tree in each plot. Daily fruit drop was counted in each plot and percent cumulative mature fruit drop calculated from the total number of fruit mechanically and hand harvested/tree on day 5 .

MAR. 2004 TRIAL-TRUNK SHAKER. Prior to application of CMNP, a 10-acre block of 12-year-old 'Valencia' orange trees on Carrizo citrange rootstock was selected in the Silver Strand North Grove near Immokalee, Fla. Within this block, 144 uniform trees at a spacing of $3.6 \mathrm{~m}$ in the row and $7.3 \mathrm{~m}$ between rows and covering slightly less than 1 acre were selected for study. Trees were divided into plots containing four adjacent trees in the row, and each plot was separated by at least two guard trees. Any ground fruit under test trees were removed. The center tree in each plot was measured for tree height and trunk circumference. A Coe-Collier trunk shaker (see above) was used to harvest trees at 2 , 4 , or 7 s shake time per tree, monitored as described in the Dec. 2003 trial. CMNP was applied at 0,125 , and 250 ppm on 25 Mar. FDF and fruit harvest variables were measured as described above. An additional measurement of crushed ground fruit after harvesting was included. Crushed ground fruit were counted, and weight for each plot was derived from piece weight measurements of harvested fruit.

APR. 2004 TRIAL-CANOPY SHAKER. A 10-acre block of 17 -year-old 'Valencia' orange on Swingle citrumelo (Citrus paradisi $x$ Poncirus trifoliata) rootstock was selected at Cooperative Producers, near Immokalee, Fla. Within this block, 192 uniform trees at a spacing of $4.0 \mathrm{~m}$ in the row and $7.3 \mathrm{~m}$ between rows and covering more than one acre were selected for study. Trees were divided into eight-tree plots, and each plot was separated by at least four guard trees. Any ground fruit under the canopies were removed. A center tree in each plot was measured for tree height and trunk circumference. Dual continuous moving canopy shakers (continuous moving canopy shaker system) (Freedom Series model 3220; OXBO International Corp., Byron, N.Y.) equipped with catch frames, traversing each side of the tree, were used in this study. Canopy shaker tines were set at a frequency of 280 cycles $/ \mathrm{min}$. 
Ground speed of the canopy shaker was $1.0,1.5$, or $2.0 \mathrm{mph}$. CMNP was applied at 0 or $350 \mathrm{ppm}$ on 22 Apr. FDF and fruit harvest variables were measured as described above.

Data analysis. Treatments were analyzed as a factorial design; with either shake time or ground speed, and CMNP concentration as factors. Analysis of variance was performed using the General Linear Model function within the SAS statistical package (SAS Institute, Cary, N.C.). Percentage data were transformed when necessary to normalize the distribution of variance. Duncan's multiple range test or orthogonal contrasts were used for mean separation or significance, depending on comparisons made.

\section{Results}

TREE UNIFORMITY WITHIN TRIALS. Height and trunk circumference of 'Hamlin' or 'Valencia' trees in each trial were not significantly different among times of trunk shaking, CMNP concentration, or ground speed of the canopy shaker (data not shown). Tree height and trunk diameter averaged 4.2 and $0.5 \mathrm{~m}$ across the three trials. Establishing tree uniformity for mechanical harvesting experiments reported in this work was important, as fruit removal can be influenced by these tree characteristics (Fridley, 1983).

DEC. 2003 TRIAL-TRUNK SHAKER. At the time of spray application (1400 HR, 4 Dec. 2003), the temperature was $81.7^{\circ} \mathrm{F}$ and fell to a low of $57.9^{\circ} \mathrm{F}$ the following night. Temperatures after spray application until harvest averaged $60.8{ }^{\circ} \mathrm{F}$. The lowest and highest hourly temperatures during this time were 38.3 and 77.5 ${ }^{\circ} \mathrm{F}$, respectively.

Post-spray drop increased with increasing CMNP concentration (Table 1). However, only post-spray drop associated with 500 ppm CMNP was significantly different from the control and represented $1.8 \%$ of the total yield. The weight of fruit harvested and caught or not caught in the catch-frame, and the weight of fruit harvested by the trunk shaker + post-spray drop were not significantly different either by duration of trunk shaking or CMNP concentration. After mechanical harvest, significantly more fruit remained in the canopy after a 2 -s shake compared with a 7-s shake. In addition, significantly more fruit remained in the canopy in trees not treated with CMNP than at any concentration. Total fruit yield was not significantly different either by duration of trunk shaking or CMNP concentration. Mature fruit removal percentage was higher in trees shaken for $7 \mathrm{~s}$ compared with $2 \mathrm{~s}$, and in trees treated with 500 ppm CMNP as compared to those treated with 125 ppm CMNP or the controls. No difference in mature fruit removal was measured between the 250 and 500 ppm CMNP treatments. Change in mature fruit removal percentage with increasing CMNP concentration was plotted for both trunk shake times. As CMNP concentration increased, percent mature fruit removal increased when trees were harvested at 2 -s shake duration, but not at $7 \mathrm{~s}$ (Fig. 1). At each CMNP concentration, fruit removal was significantly greater when harvested at $7 \mathrm{~s}$ rather than $2 \mathrm{~s}$, except at $250 \mathrm{ppm}$ CMNP. FDF was reduced from $11.0 \mathrm{~kg}$ in the controls to 7.7 , 4.6 , and $2.9 \mathrm{~kg} 4 \mathrm{~d}$ after treatment with 125,250 , and 500 ppm CMNP, respectively.

In an adjacent block of trees, reduction in FDF and increase in percent cumulative mature fruit drop was followed daily after application of various concentrations of CMNP. Application of 31.3 or $62.5 \mathrm{ppm}$ CMNP had little effect on FDF, and did not increase fruit drop when compared with the control over the 5 -d period (Fig. 2A-B). FDF was reduced by $25 \%$ in trees sprayed with $125 \mathrm{ppm}$ CMNP; however, fruit drop was not different from the control. Application of 250 or $500 \mathrm{ppm}$ CMNP resulted in marked but similar reduction in FDF over the 5-d period. Fruit drop was less in trees sprayed with $250 \mathrm{ppm}$ CMNP than 500 ppm CMNP 4 and $5 \mathrm{~d}$ after application. Changes in FDF and percent cumulative mature fruit drop for the 5-d time course followed an exponential decay relationship (Fig. $2 \mathrm{C}$ ). In general, reducing FDF to $50 \%$ or less of the control resulted in $1 \%$ or less mature fruit drop.

Mar. 2004 Trial-Trunk SHAKER. At the time of spray application (1700 HR, 25 Mar. 2004), the temperature was $73.4{ }^{\circ} \mathrm{F}$ and fell to a low of $58.6^{\circ} \mathrm{F}$ the following night. Temperatures after spray application until harvest averaged $67.8^{\circ} \mathrm{F}$. The

Table 1. Post-spray drop, fruit harvested by the trunk shaker (TS) and caught or not caught in the catch frame, total fruit harvested by the trunk shaker + post-spray drop, fruit remaining in the tree after trunk shaking, and percent mature fruit removal in 'Hamlin' orange as affected by time of trunk shaking and 5-chloro-3-methyl-4-nitro-1 $\mathrm{H}$-pyrazole $(\mathrm{CMNP})$ concentration in Dec. 2003 at Immokalee, Fla.

\begin{tabular}{|c|c|c|c|c|c|c|c|}
\hline & $\begin{array}{l}\text { Post-spray } \\
\text { drop } \\
(\mathrm{kg} / \text { tree })^{\mathrm{z}}\end{array}$ & $\begin{array}{l}\text { Fruit harvested } \\
\text { by TS and } \\
\text { caught in catch } \\
\text { frame ( } \mathrm{kg} / \text { tree })\end{array}$ & $\begin{array}{l}\text { Fruit harvested } \\
\text { by TS but not } \\
\text { caught in catch } \\
\text { frame ( } \mathrm{kg} / \text { tree })\end{array}$ & $\begin{array}{c}\text { Total fruit } \\
\text { harvested } \\
\text { by TS }+ \\
\text { post-spray } \\
\text { drop } \\
(\mathrm{kg} / \text { tree })\end{array}$ & $\begin{array}{c}\text { Fruit } \\
\text { remaining in } \\
\text { the tree } \\
(\mathrm{kg} / \text { tree })\end{array}$ & $\begin{array}{c}\text { Total fruit } \\
\text { yield } \\
\text { (kg/tree) }\end{array}$ & $\begin{array}{l}\text { Mature fruit } \\
\text { removal (\%) }\end{array}$ \\
\hline \multicolumn{8}{|c|}{ Time (s) } \\
\hline 7 & 1.7 & 166.3 & 10.1 & 178.2 & $8.6 \mathrm{~b}$ & 186.8 & $95.4 \mathrm{a}$ \\
\hline \multicolumn{8}{|c|}{$\mathrm{CMNP}(\mathrm{ppm})^{\mathrm{z}}$} \\
\hline 500 & $3.8 \mathrm{a}^{\mathrm{y}}$ & 180.8 & 11.4 & 196.4 & $11.5 \mathrm{~b}$ & 207.8 & $94.5 \mathrm{a}$ \\
\hline 250 & $1.2 \mathrm{~b}$ & 165.3 & 10.8 & 177.6 & $15.1 \mathrm{~b}$ & 192.7 & $92.1 \mathrm{ab}$ \\
\hline 125 & $0.5 \mathrm{~b}$ & 157.9 & 9.2 & 155.9 & $16.9 \mathrm{~b}$ & 172.8 & $90.2 \mathrm{~b}$ \\
\hline 0 & $0.3 \mathrm{~b}$ & 146.2 & 10.7 & 168.8 & $23.5 \mathrm{a}$ & 192.3 & $87.5 \mathrm{~b}$ \\
\hline
\end{tabular}

${ }^{\mathrm{z}} 1 \mathrm{~kg}=2.2046 \mathrm{lb} ; \mathrm{l} \mathrm{ppm}=1 \mathrm{mg} \cdot \mathrm{L}^{-1}$.

${ }^{y}$ Means within a column followed by the same letter were not significantly different as judged by Duncan's multiple range test, $P \leq 0.05$. 

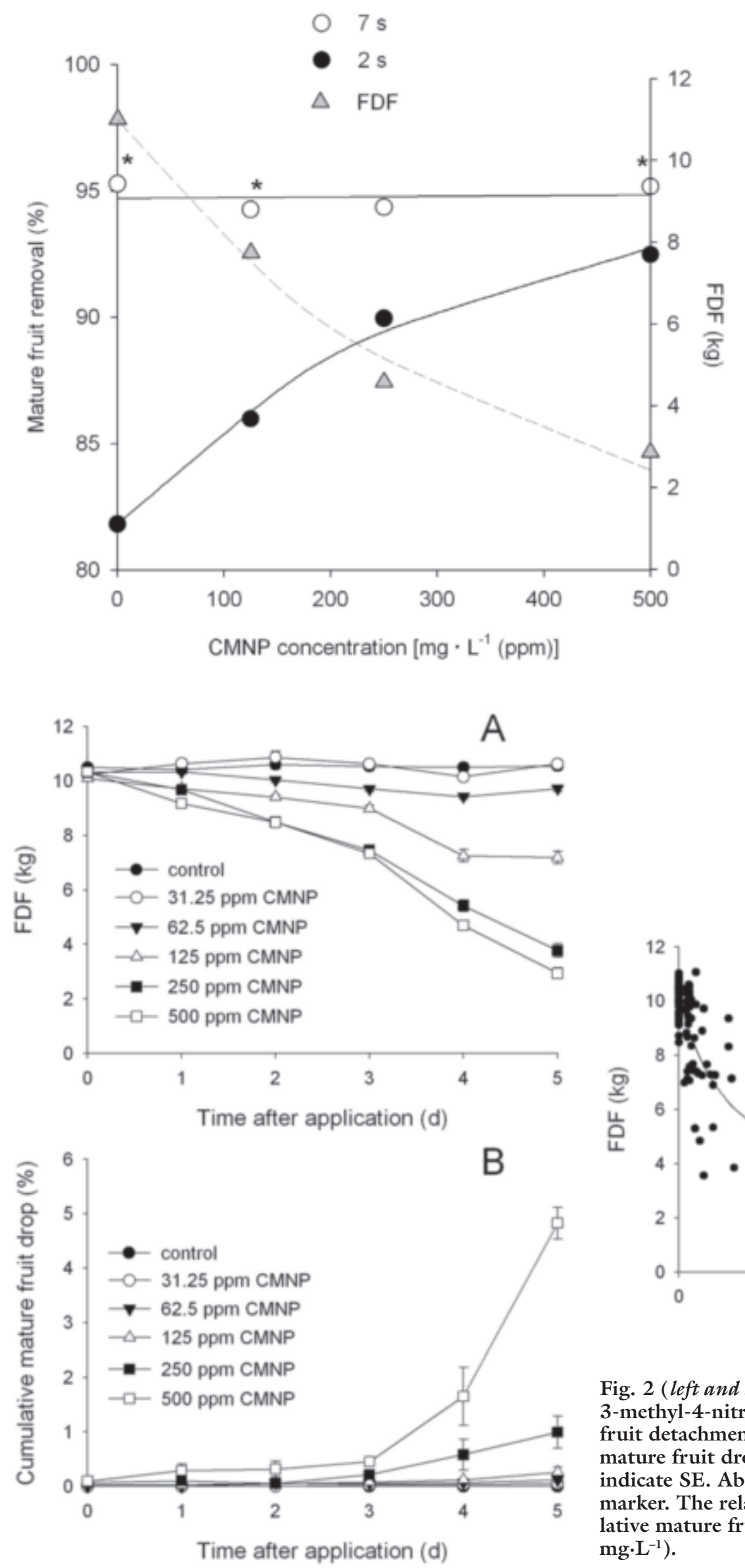
$\left.\mathrm{mg} \cdot \mathrm{L}^{-1}\right)$.
Fig. 1 (left). The effect of trunk shake time, 5-chloro-3-methyl-4nitro-1 $H$-pyrazole (CMNP) concentration and fruit detachment force (FDF) on percent mature fruit removal. * indicates statistical significance between trunk shake times at each CMNP concentration, $P \leq$ 0.05. Regression models: for $7 \mathrm{~s}, \mathrm{y}=$ $0.001 \mathrm{x}+94.708, r^{2}=0.011$; for $2 \mathrm{~s}$, $\mathrm{y}=66.977 \mathrm{x}^{0.052}, r^{2}=0.989$; for FDF, $\mathrm{y}=10.977^{-0.003 x}, v^{2}=0.985 .(1 \mathrm{~kg}=$ $2.2046 \mathrm{lb})$.

lowest and highest hourly temperatures during this time were $50.9^{\circ} \mathrm{F}$ and 82.9 ${ }^{\circ} \mathrm{F}$, respectively.

Post-spray drop was significantly higher at $250 \mathrm{ppm}$ CMNP than any other spray treatment (Table 2 ) and represented $3.2 \%$ of the total yield. No difference in fruit harvested by the trunk shaker and caught in the catch frame was measured at any time of shake or CMNP concentration. In contrast, significant differences were seen in the amount of fruit harvested by the trunk shaker but not caught in the catch frame, but these differences did not appear to be related to increased shake time or CMNP concentration. During the course of the December experiment, we noticed that harvesting equipment was crushing ground fruit not previously caught in the catch frame. Since these fruit represent a

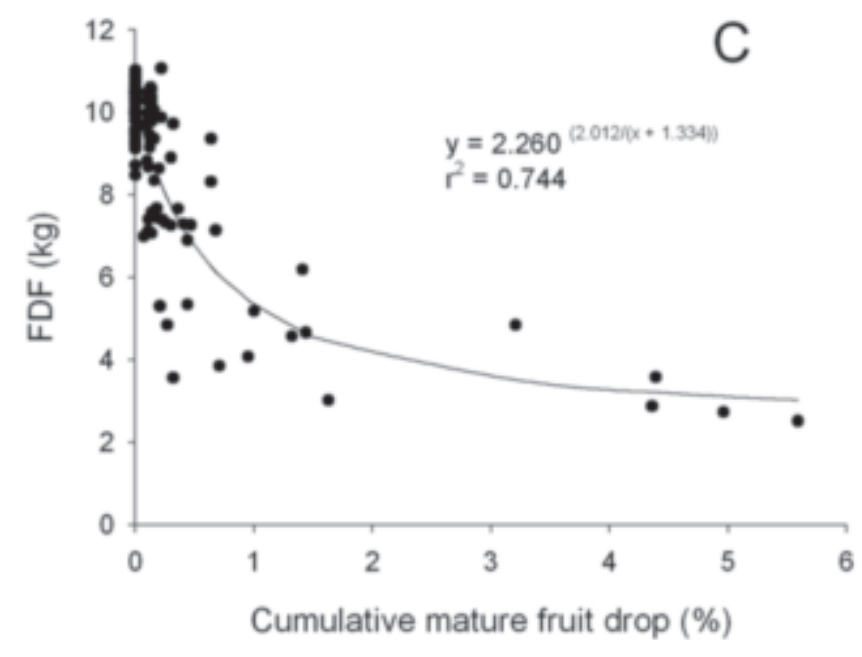

Fig. 2 (left and above). The effect of increasing 5-chloro3-methyl-4-nitro- $1 \mathrm{H}$-pyrazole (CMNP) concentration on fruit detachment force (FDF) (A) and percent cumulative mature fruit drop (B) in 'Hamlin' orange. Vertical bars indicate SE. Absence of bars indicate SE smaller than mean marker. The relationship between FDF and percent cumulative mature fruit drop $(\mathrm{C}) .(1 \mathrm{~kg}=2.2046 \mathrm{lb}, 1 \mathrm{ppm}=1$ 
Table 2. Post-spray drop, fruit harvested by the trunk shaker (TS) and caught or not caught in the catch frame, crushed ground fruit after trunk shaking, total fruit harvested by the trunk shaker + post-spray drop, fruit remaining in the tree after trunk shaking, and percent mature fruit removal in 'Valencia' orange as affected by time of trunk shaking and 5-chloro3-methyl-4-nitro-1 H-pyrazole (CMNP) concentration in Mar. 2004 at Immokalee, Fla.

\begin{tabular}{|c|c|c|c|c|c|c|c|c|}
\hline & $\begin{array}{c}\text { Post-spray } \\
\text { drop } \\
(\mathrm{kg} / \text { tree })^{\mathrm{z}}\end{array}$ & $\begin{array}{c}\text { Fruit } \\
\text { harvested } \\
\text { by TS and } \\
\text { caught in } \\
\text { catch frame } \\
\text { (kg/tree) }\end{array}$ & $\begin{array}{l}\text { Fruit } \\
\text { harvested by } \\
\text { TS but not } \\
\text { caught in } \\
\text { catch frame } \\
\text { (kg/tree) }\end{array}$ & $\begin{array}{c}\text { Crushed } \\
\text { ground } \\
\text { fruit } \\
(\mathrm{kg} / \text { tree })\end{array}$ & $\begin{array}{c}\text { Total fruit } \\
\text { harvested } \\
\text { by TS + } \\
\text { post-spray } \\
\text { drop } \\
\text { (kg/tree) }\end{array}$ & $\begin{array}{c}\text { Fruit } \\
\text { remaining } \\
\text { in the tree } \\
(\mathrm{kg} / \text { tree })\end{array}$ & $\begin{array}{c}\text { Total } \\
\text { fruit } \\
\text { yield } \\
\text { (kg/tree) }\end{array}$ & $\begin{array}{c}\text { Mature } \\
\text { fruit } \\
\text { removal } \\
(\%)\end{array}$ \\
\hline \multicolumn{9}{|c|}{ Time (s) } \\
\hline 7 & 1.8 & 124.0 & $6.7 \mathrm{~b}$ & 0.9 & 133.3 & $2.6 \mathrm{~b}$ & 135.9 & $98.2 \mathrm{a}$ \\
\hline \multicolumn{9}{|c|}{ CMNP $(\mathrm{ppm})^{\mathrm{z}}$} \\
\hline 250 & $4.4 \mathrm{a}^{y}$ & 119.3 & $8.7 \mathrm{a}$ & 1.2 & 133.6 & $2.4 \mathrm{~b}$ & 136.0 & $98.3 \mathrm{a}$ \\
\hline 125 & $1.1 \mathrm{~b}$ & 134.5 & $6.9 \mathrm{~b}$ & 1.0 & 143.4 & $3.6 \mathrm{~b}$ & 147.0 & $97.5 \mathrm{a}$ \\
\hline 0 & $0.2 \mathrm{~b}$ & 125.8 & $7.5 \mathrm{~b}$ & 0.7 & 134.6 & $11.2 \mathrm{a}$ & 146.0 & $92.6 \mathrm{~b}$ \\
\hline
\end{tabular}

${ }^{2} 1 \mathrm{~kg}=2.2046 \mathrm{lb} ; \mathrm{l} \mathrm{ppm}=1 \mathrm{mg} \cdot \mathrm{L}^{-1}$.

'Means within a column followed by the same letter were not significantly different as judged by Duncan's multiple range test, $P \leq 0.05$.

yield reduction, we quantified crushed ground fruit. The amount of crushed ground fruit was low, generally less than $0.9 \%$ of the total yield and no treatment differences were found. Weight of fruit harvested by the trunk shaker + post-spray drop was not significantly different either by time of trunk shaking or CMNP concentration. After mechanical harvest, significantly more fruit remained in the canopy after a 2 s shake compared with a 4 - or 7-s shake, and more fruit remained in trees not treated with CMNP than at any concentration. Total fruit yield did not differ between treatments. Mature fruit removal percentage was significantly higher in trees shaken for 7 or $4 \mathrm{~s}$ compared with $2 \mathrm{~s}$, and in trees treated with 250 and 125 ppm CMNP as compared to the controls. No difference in mature fruit removal was measured between trees shaken for 7 and 4 s, or the 250 and 125 ppm CMNP treatments.

The change in percent mature fruit removal with increasing CMNP concentration was plotted for the three trunk shake times. As CMNP concentration increased at each shake time, percent mature fruit removal increased (Fig. 3). In trees not sprayed with CMNP, fruit removal was significantly greater when harvested at 7 and $4 \mathrm{~s}$ rather than $2 \mathrm{~s}$. Trees sprayed with 125 ppm CMNP and harvested for $7 \mathrm{~s}$ had significantly higher percent mature fruit removal than those shaken for 4 or $2 \mathrm{~s}$. No significant differences were observed at any shake time with 250 ppm CMNP. During the course of the 4-d trial, FDF was reduced from 12.6 $\mathrm{kg}$ in the controls to 7.5 and $6.1 \mathrm{~kg}$ after treatment with 125 and 250 ppm CMNP, respectively.

Apr. 2004 TRIAL-CANOPY SHAKER. At the time of spray application (1400 HR, 22 Apr. 2004), the temperature was $84.0^{\circ} \mathrm{F}$ and fell to a low of $60.1{ }^{\circ} \mathrm{F}$ the following night. Temperatures after spray application until harvest averaged $74.3^{\circ} \mathrm{F}$. The lowest and highest hourly temperature during this time were 55.9 and 88.5 ${ }^{\circ} \mathrm{F}$, respectively.

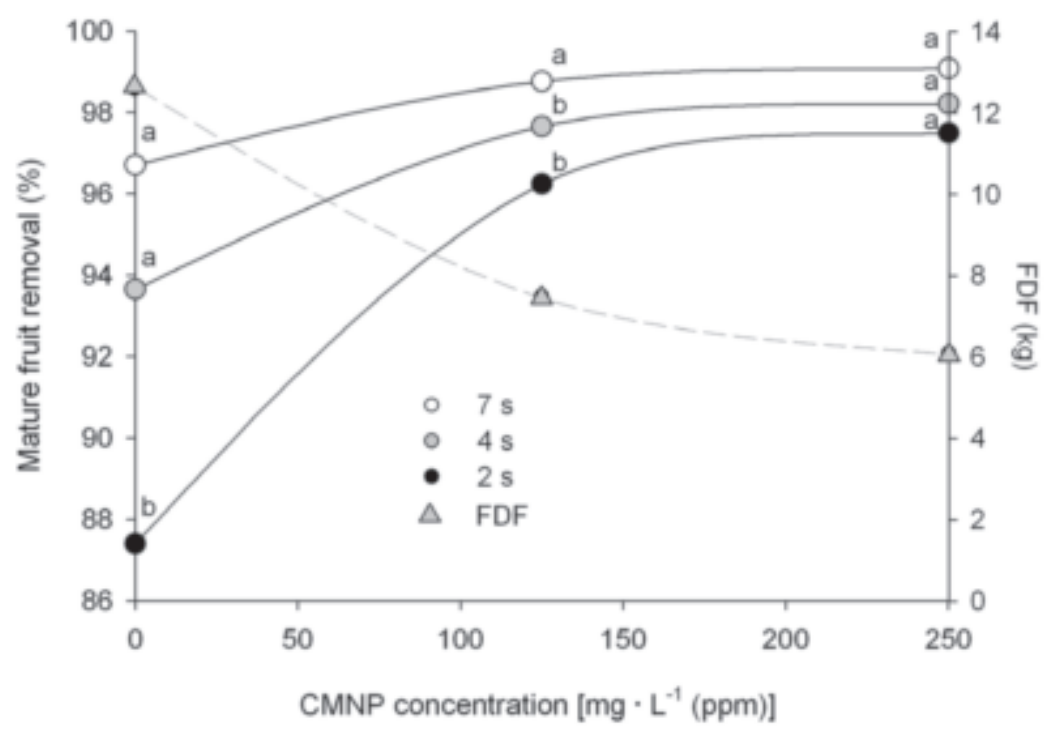

Fig. 3. The effect of trunk shake time, 5-chloro-3-methyl-4-nitro- $1 H$-pyrazole (CMNP) concentration and fruit detachment force (FDF) on percent mature fruit removal in 'Valencia' orange. Lowercase letters indicate statistical significance in mature fruit removal between trunk shake times at each CMNP concentration. Within each CMNP concentration, means followed by the same letter are not statistically different, $P \leq \mathbf{0 . 0 5}$. Regression models: for $7 \mathrm{~s}, \mathrm{y}=$ $(99.392 \mathrm{x}) /(0.805+\mathrm{x}), r^{2}=0.998$; for $4 \mathrm{~s}, \mathrm{y}=(98.769 \mathrm{x}) /(1.439+\mathrm{x}), r^{2}=$ 0.997 ; for $2 \mathrm{~s}, \mathrm{y}=(98.768 \mathrm{x}) /(3.291+\mathrm{x}), v^{2}=\mathbf{0 . 9 9 8}$; for FDF, $\mathrm{y}=\mathbf{5 . 5 7 0 +}$ $7.029^{-0.01 x}, r^{2}=0.999$. $(1 \mathrm{~kg}=2.2046 \mathrm{lb})$. 
Table 3. Post-spray drop, fruit harvested by the canopy shaker (CS) and caught or not caught in the catch frame, crushed ground fruit after canopy shaking, total fruit harvested by the canopy shaker + post-spray drop, fruit remaining in the tree after canopy shaking, and percent mature fruit removal in 'Valencia' orange as affected by canopy shaker ground speed and 5-chloro-3-methyl-4-nitro-1 H-pyrazole (CMNP) concentration in Mar. 2004 at Immokalee, Fla.

\begin{tabular}{|c|c|c|c|c|c|c|c|c|}
\hline & $\begin{array}{c}\text { Post-spray } \\
\text { drop } \\
(\mathrm{kg} / \text { tree })^{z}\end{array}$ & $\begin{array}{c}\text { Fruit } \\
\text { harvested } \\
\text { by CS and } \\
\text { caught in } \\
\text { catch frame } \\
\text { (kg/tree) }\end{array}$ & $\begin{array}{c}\text { Fruit } \\
\text { harvested by } \\
\text { CS but not } \\
\text { caught in } \\
\text { catch frame } \\
(\mathrm{kg} / \text { tree })\end{array}$ & $\begin{array}{c}\text { Crushed } \\
\text { ground } \\
\text { fruit } \\
(\mathrm{kg} / \text { tree })\end{array}$ & $\begin{array}{c}\text { Total fruit } \\
\text { harvested } \\
\text { by CS + } \\
\text { post-spray } \\
\text { drop } \\
\text { (kg/tree) }\end{array}$ & $\begin{array}{c}\text { Fruit } \\
\text { remaining } \\
\text { in the tree } \\
(\mathrm{kg} / \text { tree })\end{array}$ & $\begin{array}{c}\text { Total } \\
\text { fruit } \\
\text { yield } \\
\text { (kg/tree) }\end{array}$ & $\begin{array}{c}\text { Mature } \\
\text { fruit } \\
\text { removal } \\
(\%) \\
\end{array}$ \\
\hline \multicolumn{9}{|c|}{ Ground speed $(\mathrm{mph})^{\mathrm{z}}$} \\
\hline 2.0 & 25.3 & 106.2 & 7.7 & 1.2 & 140.3 & $15.6 \mathrm{a}$ & 155.9 & $90.1 \mathrm{~b}$ \\
\hline 1.0 & 24.2 & 123.5 & 10.8 & 1.3 & 159.8 & $8.6 \mathrm{~b}$ & 168.3 & $94.9 \mathrm{a}$ \\
\hline \multicolumn{9}{|c|}{$\mathrm{CMNP}(\mathrm{ppm})^{\mathrm{z}}$} \\
\hline 350 & $52.4 \mathrm{a}^{\mathrm{y}}$ & $90.4 \mathrm{~b}$ & 9.9 & 1.1 & 153.8 & $4.7 \mathrm{~b}$ & 158.5 & $96.9 \mathrm{a}$ \\
\hline 0 & $0.6 \mathrm{~b}$ & $135.7 \mathrm{a}$ & 8.1 & 1.1 & 145.5 & $18.4 \mathrm{a}$ & 163.9 & $88.7 \mathrm{~b}$ \\
\hline
\end{tabular}

${ }^{2} 1 \mathrm{~kg}=2.2046 \mathrm{lb} ; 1 \mathrm{mph}=1.6093 \mathrm{~km} \cdot \mathrm{h}^{-1} ; \mathrm{l} \mathrm{ppm}=1 \mathrm{mg} \cdot \mathrm{L}^{-1}$.

'Means within a column followed by the same letter were not significantly different as judged by Duncan's multiple range test, $P \leq 0.05$.

not caught in the catch frame, crushed ground fruit or total fruit harvested by the canopy shaker + post-spray drop were recorded either by ground speed or CMNP. After mechanical harvest, significantly more fruit remained in the canopy with the $2.0 \mathrm{mph}$ ground speed compared with 1.5 or $1.0 \mathrm{mph}$ ground speeds. In addition, significantly more fruit remained in the canopy in trees not treated with CMNP than at 350 ppm. Total fruit yield did not differ between treatments. Mature fruit removal percentage was significantly higher in trees harvested at ground speeds of 1.5 or $1.0 \mathrm{mph}$ compared with $2.0 \mathrm{mph}$, and in trees treated with 350 ppm CMNP as compared to the controls. No difference in mature fruit removal was measured between trees harvested at ground speeds of 1.5 or $1.0 \mathrm{mph}$. Significant interaction between variables was seen with respect to fruit remaining in the tree and percent mature fruit removal (data not shown), indicating the effect of CMNP was different at different ground speeds. In control trees, harvesting at a ground speed of $2.0 \mathrm{mph}$ resulted in significantly less mature fruit removal than the lower speeds (Fig. 4). No effect of ground speed was seen on mature fruit removal when 350 ppm CMNP was used. During the course of the 4$\mathrm{d}$ trial FDF was reduced froml $1.4 \mathrm{~kg}$ in the controls to $3.0 \mathrm{~kg}$ with CMNP (data not shown).

Orthogonal contrasts. For each harvesting trial, percent mature fruit removal of selected treatments was compared using orthogonal contrasts. In the Dec. 2003 trunk shaker

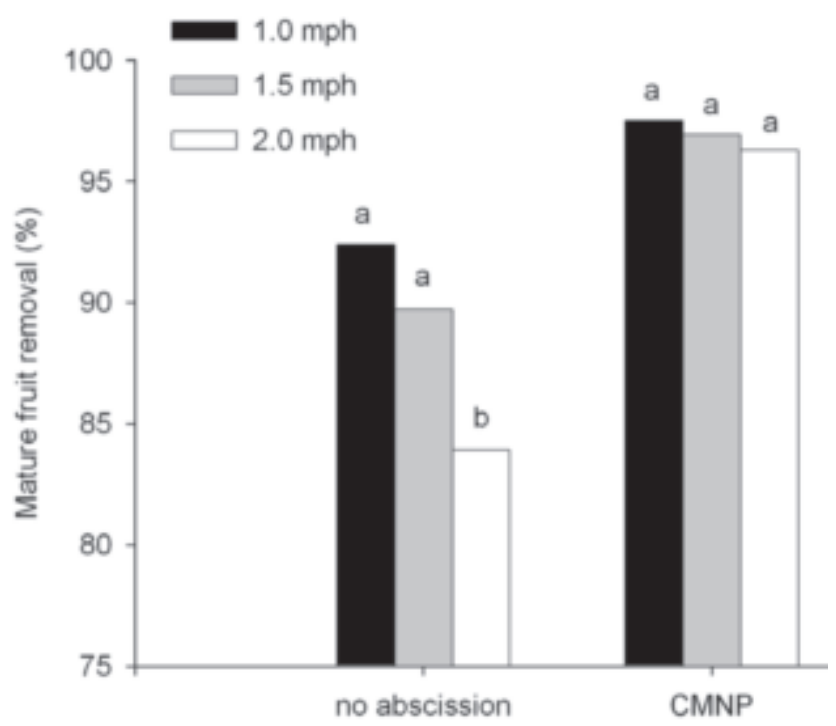

Fig. 4. The effect of canopy shaker ground speed and 5-chloro-3-methyl-4-nitro- $1 H$-pyrazole (CMNP) on percent mature fruit removal in 'Valencia' orange. Lowercase letters indicate statistical significance in mature fruit removal between canopy shaker ground speed and the control (no abscission) or CMNP treatment. Within each CMNP concentration, means followed by the same letter are not statistically different, $P \leq 0.05$. $\left(1 \mathrm{mph}=1.6093 \mathrm{~km} \cdot \mathrm{h}^{-1}\right)$.

trial with 'Hamlin' orange, mature fruit removal of the $2 \mathrm{~s}+250 \mathrm{ppm}$ CMNP treatment was not significantly different from the fruit removal of the $7 \mathrm{~s}+125$ ppm CMNP treatment (Table 4). Likewise, mature fruit removal of the $2 \mathrm{~s}+500$ ppm CMNP treatment was not significantly different from the $7 \mathrm{~s}, 7 \mathrm{~s}+125 \mathrm{ppm}$ CMNP or the $7 \mathrm{~s}+250$ ppm CMNP treatment. In the Mar. 2004 trunk shaker trial with 'Valencia' orange, mature fruit removal of the $2 \mathrm{~s}, 125 \mathrm{ppm}$ CMNP treatment was not significantly different from either the $4 \mathrm{~s}, 4 \mathrm{~s}+250$ ppm CMNP, $7 \mathrm{~s}$, or the $7 \mathrm{~s}+250 \mathrm{ppm}$ CMNP treatment. Comparison of the $4 \mathrm{~s}+125$ ppm CMNP with either the $7 \mathrm{~s}$ or the $7 \mathrm{~s}+250$ ppm CMNP treatment indicated no difference in mature fruit removal. Finally, in the Apr. 2004 canopy shaker trial with 'Valencia' orange, mature fruit removal by harvesting at $1.0 \mathrm{mph}$ ground speed was significantly different than that at $1.5 \mathrm{mph}+\mathrm{CMNP}$ and $2.0 \mathrm{mph}+$ CMNP. Comparison of the $1.5 \mathrm{mph}$ and $2.0 \mathrm{mph}+\mathrm{CMNP}$ treatment indicated that mature fruit removal was significantly different. 
Table 4. Orthogonal contrasts of selected percent mature fruit removal treatment means at various harvester settings and/or 5-chloro-3-methyl-4-nitro- $1 \mathrm{H}$-pyrazole (CMNP) combinations.

\begin{tabular}{|c|c|c|c|}
\hline $\begin{array}{l}\text { Harvest date/ } \\
\mathbf{M H}^{\mathrm{z}}\end{array}$ & Treatment & $\begin{array}{c}\text { Contrasted } \\
\text { treatment }\end{array}$ & $P^{\mathrm{x}}$ \\
\hline \multirow[t]{5}{*}{ Dec. $2003 /$ TS $^{z}$} & $2 \mathrm{~s}+250 \mathrm{ppm}^{\mathrm{y}} \mathrm{CMNP}$ & $7 \mathrm{~s}$ & $0.035^{*}$ \\
\hline & & $7 \mathrm{~s}+125 \mathrm{ppm}$ CMNP & 0.056 \\
\hline & $2 \mathrm{~s}+500 \mathrm{ppm} \mathrm{CMNP}$ & $7 \mathrm{~s}$ & 0.208 \\
\hline & & $7 \mathrm{~s}+125 \mathrm{ppm}$ CMNP & 0.335 \\
\hline & & $7 \mathrm{~s}+250 \mathrm{ppm} \mathrm{CMNP}$ & 0.141 \\
\hline \multirow[t]{6}{*}{ Mar. 2004/TS } & $2 \mathrm{~s}+125 \mathrm{ppm} \mathrm{CMNP}$ & $4 \mathrm{~s}$ & 0.087 \\
\hline & & $4 \mathrm{~s}+250 \mathrm{ppm} \mathrm{CMNP}$ & 0.186 \\
\hline & & $7 \mathrm{~s}$ & 0.753 \\
\hline & & $7 \mathrm{~s}+250 \mathrm{ppm} \mathrm{CMNP}$ & 0.061 \\
\hline & $4 \mathrm{~s}+125 \mathrm{ppm}$ CMNP & $7 \mathrm{~s}$ & 0.523 \\
\hline & & $7 \mathrm{~s}+250$ ppm CMNP & 0.332 \\
\hline \multirow[t]{3}{*}{ Apr. $2004 / \mathrm{CS}^{\mathrm{z}}$} & $1.0 \mathrm{mph}$ & $1.5 \mathrm{mph}+350 \mathrm{ppm}$ CMNP & $0.002^{*}$ \\
\hline & & $2.0 \mathrm{mph}+350 \mathrm{ppm} \mathrm{CMNP}$ & $0.005^{*}$ \\
\hline & $1.5 \mathrm{mph}$ & $2.0 \mathrm{mph}+350 \mathrm{ppm}$ CMNP & $0.001^{*}$ \\
\hline
\end{tabular}

${ }^{2} \mathrm{MH}=$ mechanical harvester; $\mathrm{TS}$ = trunk shaker; $\mathrm{CS}=$ canopy shaker.

$1 \mathrm{ppm}=1 \mathrm{mg} \cdot \mathrm{L}^{-1}$.

x Orthogonal contrasts with $P$ values of 0.05 or below are indicated by * and deemed significantly different.

\section{Discussion}

Previous reports demonstrated that CMNP could facilitate mechanical harvest by trunk shaker so that high mature fruit removal could be achieved in less time with no effect on subsequent yield (Coppock, 1975; Wilson and Coppock, 1981). In these studies and others (Whitney, 1975; Wilson and Coppock, 1968), trunk shaking was done for periods greater than 22 s, or until at least $95 \%$ mature fruit removal was achieved. Significant proprietary improvements in machine design have been made since this early work that allowed harvesting in less time per tree either with or without CMNP (Whitney et al., 2000; Figs. 1 and 3 , this work). Fruit removal was markedly increased when harvesting was done at shorter duration shake times combined with CMNP as compared with short duration shakes alone, and this provides the basis for improvements in harvesting capacity. In general, as shown in sour cherry (Prunuscerasus) (Cain, 1967), percent mature fruit removal increased as FDF decreased. Increased shake time greatly lessened the advantage of CMNP use for mature fruit removal.

A distinct advantage of abscission agent use was the ability to leave less mature fruit in the canopy after mechanical harvest and increase percent mature fruit removal. Similar advantages were measured when the trunk shaker and canopy shaker spent more time harvesting each tree (i.e., 7 $\mathrm{s}$ shake duration and $1.0 \mathrm{mph}$ ground speed, respectively). However, the benefit of abscission agent use is to be able to harvest faster, or spend less time harvesting each tree, while maintaining similar percent mature fruit removal compared to harvests done at increased tree shake times. In both the December and March trunk shaker trials, with only one exception, percent mature fruit removal was the same when reduced shake times + CMNP were compared with increased shake times either with or without CMNP. In the April canopy shaker trial, use of CMNP with intermediate and fast ground speeds significantly improved percent mature fruit removal when compared with slower speeds alone. Taken at face value, the results suggest that use of CMNP can increase harvest speed by at least two-fold. In practice, however, additional factors such as machine travel time between trees (repositioning), trunk clamp time and machine repair time will affect overall gains in harvest speed.

CMNP is a selective abscission agent that loosens mature fruit within 3 to $5 \mathrm{~d}$, depending on temperature (Burns, 2002; Yuan and Burns, 2004). During this time, post-spray fruit drop can occur. An understanding of the timing of FDF reduction and mature fruit drop is necessary to maximize fruit removal while minimizing the potential for machines to crush abscised fruit on the ground at harvest, or the need for hand crews to recover fruit on the ground before machine operation. The relationship between FDF and mature fruit drop in the December trial suggested that FDF should not decrease below $50 \%$ of the starting value to maintain post-spray drop below $1 \%$ of the total yield. This relationship generally held true in the March trial, where reduction in FDF was less than $50 \%$ with 125 ppm CMNP and postspray drop remained below $1 \%$ of the total yield. In the April trial, a higher concentration of CMNP was applied in an attempt to overcome the reduced response to abscission agents due to high endogenous auxin content in trees at this time of year (Yuan et al., 2001). Surprisingly, post-spray drop was over $33 \%$ of the total yield, indicating that trees were still fully responsive to the abscission compound. Higher temperatures during this trial may also have contributed to the outstanding loosening response. Nevertheless, despite the high concentration of CMNP applied, trees exhibited no phytotoxicity, or leaf or immature fruit loss.

Besides the advantage of high percent mature fruit removal with shorter duration tree harvesting time, another benefit of abscission agent use may be the ability to deliver more fruit to the processing plant, or increase fruit "recovery." Recovery is influenced by many factors, including post-spray drop, fruit not caught in the catch-frame, crushed ground fruit, fruit remaining in the tree, and fruit loss during transfer to hauling units. If hand harvest crews are a part of the mechanical harvesting system, these fruit can be collected and marketed; however, the expense associated with hand harvest crews should be minimized to maximize economic gains from mechanical harvesting. Provided post-spray drop can be appropriately managed so that ground fruit can be minimized, abscission agents can decrease the amount of fruit remaining in the tree after harvest. Abscission agents could reduce fruit "flinging" as a result of vigorous shaking and allow more fruit to be captured in the catchframe. In our work, no clear trend in fruit not caught in the catch-frame was measured in abscission-treated trees. In trunk and canopy shaker studies, catch-frames often did not properly seal around trunks, resulting in approximately $5 \%$ of the total yield falling to the ground. Improvements 
in catch-frames are needed to minimize this fruit loss and assess the effect of abscission agents on fruit recovery.

\section{Conclusions}

We demonstrated that harvesting capacity of trunk and canopy shakers can be improved with the use of CMNP by allowing trees to be harvested in less time while maintaining high fruit removal. Although there are clear advantages to using CMNP, temperature, cultivar and time of year may influence efficacy. More work is needed to determine the concentration needed to maximize mechanical harvesting capacity under various conditions. Currently, no abscission agents are available for use on Florida citrus, but recent efforts have been directed toward registration of CMNP. The economic benefit of increasing harvesting capacity with CMNP will ultimately be assessed when fruit recovery can be accurately evaluated and the final cost of the abscission agent and its application is known.

\section{Literature cited}

Brown, G.K. 2005. New mechanical harvesters for the Florida citrus juice industry. HortTechnology 15:69-72

Burns, J.K. 2002. Using molecular biology tools to identify abscission materials for citrus. HortScience 37:459-464.

Burns, J.K., L.V. Pozo, R. Yuan, and B. Hockema. 2003. Guanfacine and clonidine reduce defoliation and phytotoxicity associated with abscission agents. J. Amer. Soc. Hort. Sci. 128:42-47.
Cain, J.C. 1967. The relation of fruit retention force to the mechanical harvesting efficiency of Montmorency cherries. HortScience 2:53-55.

Coppock, G.E. 1975. Abscission chemicals effect on the performance of a limb shakercatching frame citrus harvest system. Proc. Fla. State Hort. Soc. 88:114-116.

Fridley, R.B. 1983. Vibration and vibratory mechanisms for the harvest of tree fruits, $\mathrm{p}$. 157-188. In: M. O'Brien, B.F. Cargill, and R.B. Fridley (eds.). Principles and practices for harvesting and handling fruits and nuts. AVI, Westport, Conn.

Koo, Y.M., M. Salyani, and J.D. Whitney. 2000. Spray variable effects on abscission of orange fruit for mechanical harvesting. Trans. Amer. Soc. Agr. Eng. 43:1067-1073.

Muraro, R.P., T.H. Spreen, and M. Pozzan. 2003. Comparative costs of growing citrus in Florida and Sao Paulo (Brazil) for the 2000-01 season. Fla. Coop. Ext. Serv. Inst. Food Agr. Sci. EDIS Publ. 29 June 2005. <http://edis.ifas.ufl.edu/FE364>.

Pozo, L., R. Yuan, I. Kostenyuk, F. Alferez, G. Zhong, and J.K. Burns. 2004. Differential effects of 1-methylcyclopropene on citrus leaf and mature fruit abscission. J. Amer. Soc. Hort. Sci. 129:473-478.

Salyani, M., E. BenSalem, and J.D. Whitney. 2002. Spray deposition and abscission efficacy of CMN-pyrazole in mechanical harvesting of Valencia orange. Trans. Amer. Soc. Agr. Eng. 45:265-271.

University of Florida. 2005. Florida automated weather network. Univ. Fla., Inst. Food Agr. Sci. 29 June 2005. <http:// fawn.ifas.ufl.edu/data/>.
Whitney J.D. 1975. Orange yield and removal studies with air and trunk shakers using two abscission chemicals. Proc. Fla. State Hort. Soc. 88:120-124.

Whitney, J.D., U. Hartmond, W.J. Kender, J.K. Burns, and M. Salyani. 2000. Orange removal with trunk shakers and abscission chemicals. Appl. Eng. Agr. 16:367-371.

Wilson, W.C. and G.E. Coppock. 1968. Chemical abscission studies of oranges and trials with mechanical harvesters. Proc. Fla. State Hort. Soc. 81:39-43.

Wilson, W.C. and G.E. Coppock. 1981. Abscission chemical effects on shakercatchframe harvest system performance and subsequent 'Hamlin' and 'Pineapple' orange yield. HortScience 16:299-300.

Wilson, W.C., R.E. Holm, and R.K. Clark. 1977a.Abscission chemicals-Aid to citrus fruit removal. Proc. Intl. Soc. Citricult. 2:404-406.

Yuan, R., U. Hartmond, and W.J. Kender. 2001. Physiological factors affecting response of mature 'Valencia' orange fruit to CMN-Pyrazole. I. Effects of young fruit, shoot, and root growth. J. Amer. Soc. Hort. Sci. 126:414-419.

Yuan, R. and J.K. Burns. 2004. Temperature factor affecting the abscission response of mature fruit and leaves to CMN-pyrazole and ethephon in 'Hamlin' oranges. J.Amer. Soc. Hort. Sci. 129:287-293. 